Knowledge Governance:

Meaning, Nature, Origins, and Implications

Nicolai J. Foss

SMG WP 12/2011

December, 2011 
SMG Working Paper No. 12/2011

December, 2011

ISBN: 978-87-91815-74-4

Department of Strategic Management and Globalization Copenhagen Business School

Kilen, Kilevej 14A

2000 Frederiksberg

Denmark

www.cbs.dk/smg 


\title{
KNOWLEDGE GOVERNANCE: MEANING, NATURE, ORIGINS, AND IMPLICATIONS
}

\author{
Nicolai J Foss \\ Department of Strategic Management and Globalization \\ Copenhagen Business School \\ Kilevej 14, 2000 Frederiksberg, Denmark \\ Tel.:(+45) 381525 62; Fax: (+45) 38152500 \\ njf.smg@cbs.dk \\ and \\ Department of Strategy and Management \\ Norwegian School of Economics and Business Administration \\ Breiviksveien 40, N-5045, Bergen, Norway \\ 01 December, 2011
}

Prepared for Anna Grandori, ed. Handbook of Economic Organization. Edward Elgar, 2012.

JEL Code: L1, L2, M1

Keywords: Governance, knowledge management, organizational economics 


\title{
KNOWLEDGE GOVERNANCE:
}

\section{MEANING, NATURE, ORIGINS, AND IMPLICATIONS}

\begin{abstract}
Assumptions about the knowledge held by economic agents have been an integral part of the theory of economic organization since its inception. However, recent work-here called "knowledge governance" — has more explicitly highlighted knowledge as both an independent and dependent variable. Thus, a spate of work in management research and new institutional economics has highlighted dimensions such as complementarity, complexity, tacitness, and so on of knowledge assets and shown how knowledge assets, thus dimensionalized, has explanatory value with respect to economic organization. However, knowledge may also be seen as being caused by governance mechanisms and structures; specifically, incentives, allocations of decision rights, organizational structure and so on influence the search for knowledge, and the creation, sharing and integration of knowledge. More philosophically, the concern with the role of knowledge in the context of economic organization prompts a reevaluation of a number of the fundamental assumptions that are often used to guide theory-building in the economics of organization (e.g., Bayesian and game theoretical foundations).
\end{abstract}




\section{INTRODUCTION}

Assumptions about the knowledge held by individuals have been an integral part of the economics of organization and governance since its inception. Thus, Knight (1921) tied the entrepreneur's judgment concerning the use of scarce resources to meet highly uncertain future consumer demands closely to the existence of the business firm (cf. Foss \& Klein, 2012, this volume), and Coase (1937) placed the epistemics of acting under uncertainty centrally in his analysis of firm organization (Langlois, 2007. The huge body of work in organizational economics that has been accumulating since the beginning of the 1970s has placed assumptions about how well agents individuals process knowledge (cognitive assumptions) and how they can gain access to knowledge (epistemic assumptions) (Goldman, 1978) center stage. ${ }^{1}$

Given the impressive pedigree of work that somehow links knowledge and economic organization, what sense can we make of the often voiced complaint that organizational economics theories somehow "neglect knowledge," expressed with different force and in different ways by many economists and management scholars (Demsetz, 1988; Winter, 1988; Kogut \& Zander, 1992; Grandori, 1997, 2001; Grandori \& Kogut, 2002)? Moreover, in what sense is "knowledge governance" something distinctive? The overall purpose of this chapter is to answer these questions.

I shall specifically argue that it is only rather recently that organizational economists and organizational scholars have begun to systematically treat knowledge in a "thick" mannerspecifically, as something that is not just an additional constraint on the maximization problem, but can be subject to transacting, organizing and governing and which can be influenced in terms of its

\footnotetext{
1 . For example, agency theory and its game theoretical foundations make several explicit, and often quite extreme, assumptions on these domains (e.g., shared common priors, common knowledge, specific assumptions about what exactly is asymmetric information) (Foss \& Stea, 2011). Equilibrium outcomes in terms of contracting, levels of monitoring, and so on are crucially dependent on what exactly is assumed about knowledge in these models. More generally, asymmetric information, ignorance about future contingencies, and ambiguity concerning contract terms ("bounded rationality") are invoked to explain imperfect and incomplete contracting, ownership patterns, and incentive design.
} 
growth, change, composition, and so on by the deployment of governance structures (Williamson, 1996) and mechanisms (Grandori, 1997). In fact, this is (one interpretation of) what is meant by "knowledge governance" (Foss, 2007). Thus, much of the impetus behind the recent interest in knowledge governance has emerged from the critique of organizational economics on the part of those who endorse the "knowledge-based view of the firm" (in its various incarnations). The critics argue that organizational economics tend to treat production knowledge as essentially homogenous across firms in an industry, flying in the face of a reality of differential capabilities. Echoing Richardson (1972), these writers argue this matter because differential capabilities are determinants of economic organization (notably the boundaries of the firm) on par with (or, perhaps even more important than) such determinants as asset specificity, frequency and uncertainty (e.g., Langlois, 1992; Jacobides \& Winter, 2005). As Argyres, Felin, Foss and Zenger (2011) note, a number of prominent organizational economists_-including Holmström and Roberts (1998) and Williamson (1999) — have, somewhat surprisingly, accepted this argument. However, as Argyres et al. also note, the knowledge-based view gives complete explanatory primacy to capabilities, and fails to acknowledge that governance structures and mechanisms may antecede capabilities. In fact, a key explanatory purpose of knowledge governance may indeed be the explanation of heterogeneous firm-level capabilities. I end by discussing this and other frontier issues, notably the inclusion of the governance of beliefs and cognitions in the knowledge governance project.

\section{WHY "KNOWLEDGE GOVERNANCE"?}

\section{Origins}

The origins of knowledge governance are manifold. In their Organization Science dialogue on the "knowledge and organization" nexus, Grandori and Kogut (2002) point to influences such as the growth of knowledge literature in the philosophy of science, the vast body of work on technology transfer, the organizational learning literature, and evolutionary economics. This pedigree supplies 
the "knowledge" part. In terms of the "governance" part, knowledge governance is nourished by the fields of organizational design theory and organizational economics (Grandori, 2001a; Foss, 2007).

In a broader context, "knowledge" has been all the rage for more than a decade in a number of fields in management studies (e.g., Grandori \& Kogut, 2002; Eisenhardt \& Santos, 2003). Thus, a "knowledge movement" that cuts across traditionally separate disciplines in management research has emerged. The strategy field has a number of approaches that place (firm-level) knowledge (e.g., capabilities and competences) center stage (e.g., Grant, 1996; Spender, 1996; Kogut and Zander, 1996); the international business field is in the process of developing a view of the multinational corporation as a knowledge-based entity (Tallman, 2003); network ideas that stress connections between knowledge nodes, often based on sociological notions of network ties (Granovetter, 1973),

are becoming increasingly influential (Kogut, 2000; Ghoshal \& Tsai, 1998; Tsai, 2001, 2002); and, of course, knowledge management has become not only a huge body of literature, but also a widespread organizational practice (Easterby-Smith and Lyles, 2003; Spender, 2005). What unites these ideas is the notion that the management and governance of knowledge of whatever kind has become a critical issue for competitive dynamics, international strategy, the building of resources, the boundaries of firms, and many other issues.

\section{The Context: New Phenomena in Need of Explanation}

The origin of knowledge governance as an emerging field may also be seen in the context of a number of new explananda for organizational research that became increasingly visible with the advent of a number of tendencies that are often summarized under the rubric of the "knowledge economy" (Foss, 2005). Among these tendencies is the increasing importance of human capital inputs, immaterial assets and scientific knowledge in production, the increasing importance of immaterial products, the need to control inhouse an increasing number of technologies (even if product portfolios are shrinking) (Brusoni, Prencipe \& Pavitt 2001), and in general to tap an 
increasing number of knowledge nodes, not just through internal but also through an increasing number of alliances and network relations with other firms as well as public research institutions (Doz et al. 2004). These tendencies are often seen as profoundly impacting economic organization and competitive advantages (Carmuffo, 2002; Ewing, 2002; Garicano \& Rossi-Hansberg; 2003; Adler, 2001). However, the mechanisms through which this takes place are not always transparent, and part of what knowledge governance is up to may be understood as an attempt to theorize such mechanisms.

Much emphasis has been placed on the strongly growing importance of human capital as a driver of changes in economic organization (e.g., Rajan \& Zingales, 2001). In management research the increasing importance of human capital has been reflected in notions of "knowledge workers" (Zuboff, 1988) and "knowledge-intensive firms" (Starbuck, 1992), that is, “... organizations staffed by a high proportion of highly qualified staff who trade in knowledge itself”' (Blackler, 1995: 1022). According to a prominent argument, such firms may be differentiated from "traditional" firms in terms of organizational control by relying less on direction through the exercise of authority, eschewing high-powered performance incentives, and embracing "culture" and "clan" modes of organizational control. According to some this is more akin to a revolution than a gradual evolution; as Zingales (2000: 1641) argues: “... in 1994 a firm like Saatchi and Saatchi, with few physical assets and a lot of human capital, could have been considered an exception. Not anymore. The wave of initial public offerings of purely human capital firms, such as consultant firms, and even technology firms whose main assets are the key employees, is changing the very nature of the firm."

Virtually all of those who have written on the subject agree that tasks and activities in the knowledge economy need to be coordinated in a manner that is quite different from the management of traditional manufacturing activities. However, there is considerable divergence in the accounts of what exactly are the changed coordination requirements in the knowledge economy. 
Thus, some argue that "traditional" coordination mechanisms such as price, authority, routines, standardization, etc. will diminish in relative importance, because knowledge-intensive production requires the increased use of mechanisms such as trust, communication, community, democratic procedures, etc. that can better cope with the particular metering problems and exchange hazards that are characteristic of knowledge transactions (e.g., Ghoshal, Moran \& Almeida-Costa 1995). These scholars typically also argue that the increasing reliance upon cross-functional processes, extensive delayering, and empowerment reflect an aim is to create highly specialized and motivated units by means of extensive delegation of discretion. Cross-functional processes substitute for hierarchy in the coordination of tasks. Scholars promoting this view will tend to see the boundaries of firms blurring and employment relations undergoing dramatic change as a result of knowledge networks increasingly cutting across the boundaries of the firm and participative governance being increasingly adopted. Others take a more hard-nosed and less rosy view of the ongoing changes in economic organization. An important part of the tendencies constituting the knowledge economy are an intensification of competition as industry boundaries are eroded, and as internationalization and liberalization increase. In response to such competitive pressures, as Adler (2001: 220) points out, “... firms are fine-tuning their management structures and planning processes, demanding greater accountability at every level, and enforcing more discipline in the planning and execution of operations." As Zenger and Hesterly (1997) note, improved methods of cost allocation, more widespread use of IT and better measures of input and output performance have decreased the costs of monitoring employees and organizational units, in turn promoting a tendency to smaller organizational units that face more high-powered incentives.

With respect to the boundaries of the firm, many management scholars argue that trust-based ("community"-based) forms of organization emerge that can better handle "innovation tasks" (idem.). Others point out that “... the buffering functions of management are devolving to the 
mechanisms of modularity and the market - informational decomposition, flexibility and risk spreading" (Langlois, 2003: 376). This does not necessarily imply that the boundaries of firms blur; rather, firms specialize and disintegrate. Also, while a modular system often internalizes knowledge-intensive transactions in modules, it is entirely consistent with innovative efforts (Langlois \& Robertson, 1995). Thus, the information and knowledge richness associated with innovative efforts does not necessarily imply trust, rich information and knowledge transfer between firms, etc.

In sum, the emergence of the knowledge economy has given rise to a rich debate on the nature of the knowledge-based drivers of changing economic organization, as well as how economic organization influences knowledge processes. Theorizing the underlying mechanisms may be seen as the essence of knowledge governance.

\section{Meaning}

The term "knowledge governance" seems to have been first used by Grandori (2001). She offers a series of examples of "governance mechanisms" (a possible second terminological innovation) that support such processes as knowledge sharing and integration. Thus, decision rights, routines, rewards, modes of communication and so on are governance mechanisms that can be combined in multiple ways across governance structure and influence various knowledge-related processes via their effects on individuals' knowledge sharing, creating, integrating, etc. behaviors. This conceptualization treats "knowledge" as a dependent variable, endogenous to governance. However, no explicit definition of knowledge governance (as a new field or a new construct) is proffered. In Grandori's “dialogue on organization and knowledge" with Bruce Kogut, she (Grandori \& Kogut, 2002: 225) explains that an important way in which knowledge approaches have contributed “... is in providing a new 'contingency' factor for understanding organizational arrangements, as well as to suggest new ways to conceive the nature of organizational 
contingencies. Knowledge complexity, differentiation, specialization, complementarity, and interdependence are emerging as important contingencies affecting effective organization and governance solutions." This treats knowledge (characteristics) as an independent variable, driving governance.

There is, of course, nothing wrong in treating "knowledge" as both dependent and independent variables. Thus, some knowledge assets may effectively be thought of exogenous; for example, capabilities take time to change. Other aspects of knowledge may be thought of as endogenous, and partly influenced by exogenous knowledge variables; for example, outcomes of knowledge integration processes in a firm may be constrained (or facilitated) by the capabilities that are controlled by the firm. Moreover, in a dynamic analysis, one period's exogenous variables may be taken to be next period's endogenous variables. Thus, capabilities may be taken as exogenous in the short-run; however, they are obviously endogenous in the longer run. ${ }^{2}$

Nevertheless, for heuristic purposes it makes sense to distinguish "knowledge governance with knowledge treated as an exogenous variable" and "knowledge governance with knowledge treated as an endogenous variable." Given this, knowledge governance in the former sense may be defined as a sustained attempt to uncover how knowledge transactions-which differ in their characteristics - and governance mechanisms — which differ with respect to how they handle transactional problems_-, are matched, using economic efficiency as the explanatory principle. This is how knowledge governance is explicitly defined in Foss (2007), and more implicitly in, for example, Silverman (1999) and Nickerson and Zenger (2004), all papers that take their primary cues from organizational economics (particularly transaction cost economics). However, much of the capabilities perspective as it applies to governance issues also adopts the "knowledge

\footnotetext{
${ }^{2}$ While organizational economics suggests that both "knowledge" (e.g., human capital investments) and "governance" (e.g., ownership patterns) are chosen simultaneously (as in Hart, 1995), and thus both are choice variables, the choice itself may still be constrained by pre-existing capabilities. For example, some human capital investments make sense, given the business that the firm is in, while others do not.
} 
governance with knowledge treated as an exogenous variable" approach. Specifically, capabilities writers adopt a "capabilities first" heuristic according to which capabilities have explanatory primacy relative to governance considerations, and can, for the purposes of explaining economic organization (typically, the boundaries of the firm), be taken as exogenous (e.g., Kogut \& Zander, 1992; Madhok, 1996).

We may also think of a knowledge governance approach in which "knowledge" is endogenous in the sense that the focus is on how governance structures and mechanisms influence knowledge-related behaviors, such as individual knowledge sharing, integration, creation, forgetting, and so on. Much management research in organizational theory, international business, strategic management, knowledge management and technology strategy has adopted such an approach (without calling it "knowledge governance"). Team theoretical work in organizational economics may also qualify as a knowledge governance approach in this sense, as the focus in team theory is on how the design of communication channels and the allocation of decision rights influence organizational outcomes, such as the rate of approval/rejection of innovation projects (i.e., knowledge creation) (Marschak \& Radner, 1972; Sah \& Stiglitz, 1985, 1986; Garicano, 2000). Economics work on human capital in labor economics and on entrepreneurship also has a bearing on knowledge governance (for details, see Foss \& Mahnke, 2003).

\section{KNOWLEDGE GOVERNANCE WITH EXOGENOUS KNOWLEDGE}

\section{Capabilities and Economic Organization}

While knowledge governance is positioned in the broad "knowledge movement" (Eisenhardt \& Santos, 2003; see also Grandori \& Kogut, 2002), in historical and substantive terms it owes much to the long-standing capabilities critique of organizational economics. Capabilities theorists forward that capabilities ideas hold the key to understanding organizational heterogeneity — a key issue in strategic management and other management research fields — while organizational economics is 
largely silent about this issue. To the extent that such heterogeneity matters to economic organization - notably, the boundaries of the firm - the capabilities view therefore holds explanatory primacy.

The first contribution in the research literature to make use of the "capabilities" terminology in the context of understanding economic organization and make the above arguments is Richardson (1972). Drawing on Penrose (1959), Richardson (1972: 888) argues that explaining the "division of labour between firm and market" requires that we place the "elements of organisation, knowledge, experience and skills" center stage. In a footnote, he mentions Coase's (1937) explanation of the boundary costs in terms of the relative costs of using firms versus markets as basic coordination modes, and adds that the "explanation that I have provided is not inconsistent with his but might be taken as giving content to the notion of this relative cost by specifying the factors that affect it" (Richardson, 1972: p.888n). ${ }^{3}$

Partly because capabilities idea did not catch on in management research and economics until the end of the 1980s, the discussion lay dormant for almost two decades. However, it was revitalized in 1988 in important contributions by Demsetz (1988) and Winter (1988). Both argued that the economics of the firm neglected firm-specific knowledge and how it shapes the boundaries of the firm. Later papers by Kogut and Zander (1992, 1996), Madhok (1996), Conner and Prahalad (1996) and others aggressively argued that economic organization was fully explainable in capabilities terms, and that no use need to be made of the notion of opportunism (or moral hazard, or misaligned incentives in general; for a critique of this position, see Foss, 1996a). This position seems to have been abandoned in favor of an argument that capabilities ideas and organizational economics are complementary in an additive manner. In such an understanding, for example,

\footnotetext{
${ }^{3}$ Unlike most subsequent research, Richardson explicitly dimensionalizes capabilities (in terms of the extent to which capabilities in adjacent stages of the value chain are "similar" and "complementary") and argues that the resulting taxonomy has direct implications for the boundaries of the firm. Thus, he argues that similar and highly complementary capabilities should be organized by a firm, while dis-similar but highly complementary capabilities give rise to hybrid organizational forms, and dissimilar and complementary capabilities are best organized by the market).
} 
capabilities theory informs us about which resources are need(to position in an industry and compete in certain ways, while organizational economics informs us about the optimal sourcing and organization of such resources. Such an understanding of the relation between the two perspectives is explicit or implicit in much work over the last decade or so (e.g., Argyres, 1996; Silverman, 1999). It may have been given legitimacy among those who subscribe to organizational economics by the fact that Williamson (1999) seemed to endorse it. Arguments that stress the additive complementarity of different theories are often made in management research (e.g., Mahoney \& Pandian, 1992). Note, however, that accepting the argument that complementarity obtains in an additive manner is implicitly a call for giving up theory development in the intersection of capabilities theory and organizational economics; in fact, it is a denial that there is a meaningful shared domain of application, because it implies that the relevant theories address different explanandum phenomena. Therefore, they are not theoretical rivals.

\section{Capabilities First!}

However, some work has explored relations of complementarity that goes beyond the additive in greater detail. Such work recognizes that there is a meaningful zone of overlap between the capabilities view and organizational economics. In contrast to earlier contributions it is recognized that the theories are not rival, or additive, but that the variables identified in the different approaches may be seen as interacting in an essential manner. For example, Mayer and Argyres (2004) and Argyres and Mayer (2007) conceptualize transacting (i.e., contracting) as a learned capability. Learning in a contractual relation reduces transaction cost; as a result changes in contract terms can be observed that are not explainable in terms of changes in asset specificity but rather in terms of learning and capability. In early work that also stressed genuine complementarity, Langlois (1988, 1992) argued that transaction costs may moderate the link from the capability distribution in an industry to vertical scope. Specifically, he argued that under dynamic conditions firms may not be 
able to access the services they wish to access; suppliers may not understand what exactly is required of them. Such communication costs (Langlois calls them "dynamic transaction costs") may drive boundary decisions in dynamic environments (see also Teece, 1977), while the more conventional transaction costs of transaction cost economics drive boundary decisions in more static environments. ${ }^{4}$ In Langlois' approach, capabilities are primary; transactions costs enter as a moderating force. Although written from a transaction cost perspective, the Mayer and Argyres paers also exemplify the dominance of capabilities: Their argument assumes that learning and capabilities drive governance, rather than the other way around

The dominance of the "capabilities first!" heuristic is arguably caused by a prevalent conception that capabilities ideas remain our best shot at a theory of organizational heterogeneity and that they encapsulate heterogeneous resources, routines, coordination mechanisms, identity and so on. "Capabilities" is a much richer construct than, say, "asset specificity." Organizational economics has typically not emphasized organizational heterogeneity, which has not traditionally been seen as either part of the explanans or the explanandum phenomena of organizational economics. Thus, there is little in, for example, Williamson (1996) or Hart (1995) that suggests why firm should be heterogeneous with respect to how they organize production and conduct transactions. Because the capabilities construct is first and foremost designed as an encapsulation of organizational heterogeneity, it has played essentially no role in mainstream organizational economics.

\section{Dimensionalizing Knowledge and Identifying Knowledge-related Exchange Hazards}

\footnotetext{
${ }^{4}$ In a related later paper, Jacobides and Winter (2005) build a model of industry evolution that ostensibly studies the coevolution of firm capabilities and the costs of transacting and organizing. However, in spite of the announced coevolution of transaction costs and capabilities, in actuality capabilities have explanatory primacy in this paper-as indeed in the rest of the literature on capabilities and transaction costs. Thus, capabilities and learning directly influence transaction cost, rather than the other way around; while the capabilities view and organizational economics are both part of the same theoretical edifice, the foundation consists of capabilities ideas.
} 
While arguments linking capabilities and economic organization have often been made in the management literature, the notion of "capability" is, however, a macro-construct that easily suppresses the fine grain of the mechanisms that link knowledge and economic organization. ${ }^{5}$ In contrast, the transaction, the contract or the individual agent are units that are more easily identified, dimensionalized and given to empirical measurement. Indeed, the absence of a clear unit of analysis has been highlighted as a source of confusion in the knowledge movement (Williamson, 1999). Is it routines (Nelson and Winter, 1982), or dynamic capabilities (Teece, Pisano \& Shuen, 1997), or practices (Spender, 2005), or knowledge assets (Winter, 1987)?

Disciplines, fields, or approaches are not necessarily characterized by unique units of analysis. Thus, the existing diversity when it comes to addressing knowledge in organizations may simply reflect that different research problems are involved. In general, what is the preferred unit of analysis should depend on the relevant research problems. The unit may thus differ depending on whether the focus is, for example, on knowledge sharing, integration or creation inside the firm, or how knowledge that, in some sense, resides on the firm-level impact firm boundaries. Knowledge governance issues are inherently multi-level and require multi-level theory and empirics. Moreover, the relevant units of analysis may differ, depending on the explanatory purpose at hand

That being said, however, some units of analysis seem to be more generally applicable than other ones. Perhaps the most generally applicable unit of analysis for the kind of problems that knowledge governance seeks to solve is the knowledge transaction, that is, the transfer of an identifiable "piece" of knowledge from one actor to another one (Contractor \& Ra, 2002). Most knowledge governance issues seem somehow reducible to this transactional level. This also holds for macro arguments that posit that the boundaries of the firm are shaped by the firm-level

\footnotetext{
${ }^{5}$ As Argote and Ingram (2000: 156) noted, to the extent that there has been progress in studying knowledge as the basis of competitive advantage, “.. it has been at the level of identifying consistencies in organizations' knowledge development paths and almost never at the level of human interactions that are the primary source of knowledge and knowledge transfer." In contrast, organizational economics is unabashedly methodologically individualist, and therefore seek to highlight action and interaction in the explanation of governance.
} 
idiosyncratic knowledge (e.g., Kogut \& Zander, 1992), for such arguments implicitly appeal to mechanisms involving knowledge transfer that ultimately turn on individuals (e.g., Langlois, 1992). More generally, knowledge processes, such as knowledge sharing, integration, and creation, as reduceable to (sequences of) knowledge transactions.

Taking the knowledge transaction as unit of analysis obviously has the added benefit of linking up with organizational economics and an established framework for linking transactions to alternative kinds of organizing. However, the way of dimensionalizing transactions that has become dominant in organizational economics, namely the transaction cost economics triad of frequency/uncertainty/asset specificity, seems incomplete for the purposes of dimensionalizing knowledge transactions (cf. also Grandori, 2001a; Heimann \& Nickerson, 2002; Nickerson \& Zenger, 2004). It is not clear how dimensionalizing a knowledge transaction in these terms assist the understanding of, for example, knowledge sharing where transactional problems may be caused more by the degree of codification of the relevant knowledge than its "uncertainty" (whatever that might mean in the specific context). The knowledge-based literature has not been very successful with respect to forwarding theoretically, dimensionalizations of knowledge. ${ }^{6}$ An exception is the Winter (1987) taxonomy, which has been the basis for much subsequent empirical work (e.g., Kogut \& Zander, 1993; Simonin, 1999; Grandori \& Kogut, 2002, and which presents the the dimensions of tacitness vs. explicitness, system-quality vs. stand-alone, teachability vs. nonteachability, and complexity vs. non-complexity. Although these dimensions have usually been applied to more aggregate knowledge constructs (such as routines and capabilities) in the empirical literature, they may also be used to characterize knowledge transactions. Other dimensions may be relevant. For example, scholars working from a transaction cost economics perspective have

\footnotetext{
${ }^{6}$ The many studies of inter-firm imitation and intra-firm knowledge transfer (e.g., Maritan \& Brush 2003) tend to develop dimensions of, say, capabilities in an inductive manner and the explicit or implicit dimensionalizations differ from study to study.
} 
suggested adding "appropriability" as a relevant dimension (e.g., Oxley, 1997), and Contractor and Ra (2002) suggest adding how "novel" the knowledge is (knowledge with a higher degree of novelty is more costly to contract, absorb, assimilate, integrate, etc.).

In the context of knowledge governance, the import of dimensionalization the unit of analysis is that the costs of sharing, integrating, and creating knowledge vary systematically with the relevant dimensions, and that the deployment of governance mechanisms to curb such costs should take this into account. Thus, along the same lines of reasoning as in standard transaction cost economics, knowledge transactions give rise to organizational hazards and costs depending on how they score in terms of the above dimensions. For example, in the context of sharing knowledge, knowledge transactions that are characterized by [explicitness, stand-alone, high teachability, noncomplexity] are less costly to govern than knowledge transactions that score opposite on these characteristics. Transactions (in the context of knowledge sharing) that involve knowledge that is new, tacit, has significant system-quality, is hard to teach, etc. are associated with cost of transmitting the knowledge from sender to receiver, (measurement) costs of ascertaining the extent to which knowledge has been shared, (monitoring) costs of inspecting input performance, and other well known organizational costs. This treats governance as endogenous to knowledge characteristics. However, it also possible to consider the reverse causality.

\section{KNOWLEDGE GOVERNANCE WITH ENDOGENOUS KNOWLEDGE}

\section{Governance Driving Knowledge: The Economics of the Firm}

Williamson (1985) admits that transaction cost economics "freezes" technology, at least as a heuristic starting point. This would seem to rule out the possibility that governance can antecede knowledge in the sense that the choice of governance structures and the deployment of governance mechanisms within those structures influence the amount, type, quality and so on of the knowledge that is shared, integrated, created, etc. However, one should not confuse heuristic assumptions with 
substantive theory. In fact, classical organizational economics has right from the beginning identifiied many theoretical mechanisms that have the potential to link governance and knowledge (although, as we shall see, that potential has mainly been realized in management research).

Thus, Alchian and Demsetz (1972) argued that a key purpose of the "specialized surrogate market" of the firm is to gain superior (relative to other firms) knowledge about productivities, and the efficient matching of employees and activities. Thus, the existence of the firm is directly linked to the ability to gain and deploy superior knowledge. A similar argument can be derived from Williamson, Wachter and Harris' (1975) point that an advantage of intrafirm labor allocation is that it can take advantage of costly to communicate rating information. Alchian (1984) stressed the relational rents stemming from improved information gained by repeated association. Such rents rooted in superior knowledge may give rise to opportunistic haggling that is best controlled within the firm.Sah and Stiglitz (1985) explained how organizational structures may be conceptualized as structures for evaluating projects, and different structures will yield different evaluation outcomes. Thus, the knowledge-related activity of evaluating, for example, innovation projects, is directly linked to internal organization. Jensen and Meckling (1992) examine how delegation of decision rights influence the utilization of locally held knowledge, which places knowledge utilization centerstage. Many papers in agency theory have explicitly linked organizational practices, such as the up-or-out mechanism, to human capital accumulation (Prendergast, 1993).

A compact way of understanding "governance" is that it is the formal and informal allocation of decision (or property) rights and the mechanisms that enforce such rights (Jones, 1983). This rights allocation and the accompanying enforcement mechanisms constitute the distribution of authority, the attributes of governance mechanisms, organizational structure, and other aspects of formal organization, but clearly also relates to, for example, social ties and networks inside firms. An allocation of property rights is also an allocation of incentives (Barzel, 1997), including 
incentives to search for knowledge, share knowledge, accumulate human capital, leverage knowledge capital, etc. Moreover, property rights influence bargaining powers (Hart, 1995). Thus, the allocation of property rights, both in terms of overall governance structures (i.e., the allocation of ownership rights) and the governance mechanisms inside those structures (which specify the allocation of, e.g., decision rights), would be expected to influence knowledge processes. For example, the specification of income rights in a governance structure directly influence how much each participating individual appropriates of the value created by interaction in the relevant governance structure. Appropriation matters to knowledge processes, for example, because employee incentives to search for, share, create, and integrate knowledge are influenced by how much they can appropriate. ${ }^{7}$

Thus, several theoretical mechanisms link governance and knowledge. It is true that organizational economics has refrained from making the issue of why such mechanisms should work differently in different firms a major issue (in this sense, the capabilities critique is valid). However, it is not at variance with organizational economics to posit that managers face different constraints, or have different utility functions, and will therefore make different choices. Neither is it inconsistent with organizational economics to posit that such choices are path-dependent (Williamson, 1996; Argyres \& Liebeskind, 1999). Thus, the mainstream economics of the firm has a huge potential to effectively deal with knowledge governance issues. However, so far rather few organizational economists have risen to the challenge (but see, e.g., Garicano, 2000).

\section{Governance Driving Knowledge: Beyond the Mainstream Economics of the Firm}

In contrast, the exploration of knowledge governance has been thriving in management research. Thus, different branches of management research provides examples of work in the

\footnotetext{
${ }^{7}$ For example, social ties and networks are important for understanding the links between knowledge and superior returns, not just because of their potentially beneficial effects on returns, but also because such ties and networks grant legitimacy to the claims that employees may make on rents (Coff \& Blyler, 2003).
} 
"governance driving knowledge" vein — such as work relating to how multinational corporations leverage human resource management systems to promote knowledge transfer between subsidiaries (cf. Minbaeva et al., 2003); research into how governance mechanisms are deployed to knowledgebased strategic alliances (Mowery et al., 1996; Oxley, 1997; Heimeriks \& Duyster, 2006); work on the governance of human capital-intensive organizations (Child \& McGrath, 2001; Teece, 2003); the organizational antecedents to the absorption of knowledge held by outside stakeholders (Janssen et al., 2006; Foss, Laursen \& Pedersen, 2011); the link between control of knowledge assets and the appropriation of surplus from relations (Coff, 1999; Coff \& Blyler, 2003); the provision of rewards to knowledge workers (Osterloh \& Frey, 2000; Reinholt, Pedersen \& Foss, 2012); and the impact of job design and communication on the motivation to share knowledge (Foss, Minbaeva, Reinholt \& Pedersen, 2009). This research stream took off at the end of the 1990s, as the emerging knowledge movement in management research made contacts with scholars who worked on organizational structure, design and HR issues, often from a partly economics-based perspective.

Thus, in an early and influential paper Osterloh and Frey (2000) examine how knowledge transfer is influenced by organizational design. They identify a number of exchange hazards that beset internal knowledge transactions, argue that the transfer of tacit knowledge cannot be accomplished by contracting, and point out that it is difficult to sanction employees for holding back tacit knowledge. Therefore, the management of individual motivation becomes central. Firms have access to mechanisms (that markets don't) to manage intrinsic motivation, such as participation which signifies agreement on common goals and raises employees' self-determination, thereby strengthening intrinsic motivation and personal relationships. In turn, this allows for establishing psychological contracts based on emotional loyalties, which in turn raise the intrinsic motivation to cooperate. In contrast, too heavy-handed use of market-like incentives may crowd-out intrinsic motivation. This paper is one of the first of an increasing number of papers that link 
governance and knowledge processes in an explicit multi-level argument through the mediating effect of employee motivation (e.g., Gottschalg \& Zollo, 2007; Minbeava et al., 2003; Foss, Minbaeva, Pedersen \& Reinholdt, 2009).

Nickerson and Zenger (2004) seek to combine transaction cost economics and complexity theory (Simon, 1962; Kauffman, 1995) in the explanation of how alternative organizational forms influence the efficient production of valuable knowledge. The unit of analysis for knowledge generation is a specific problem, whose value is determined by the values in the array of possible solutions and the cost of discovering a particularly valuable problem. The solution to complex problems is assumed to represent unique combinations or syntheses of existing knowledge. Problems differ according to their decomposability. Decomposable problems involve limited interaction, whereas non-decomposable problems involve extensive interaction. This has important implications for the type of searching for a solution. Non-decomposable problems require individuals to share their specialized knowledge, which raises knowledge-related exchange hazards. Three distinct governance structures and their suitability for problems with differing characteristics are examined: markets, authority-based hierarchies and consensus-based hierarchies. Briefly, markets are ideally suited when problems are decomposable and directional search is desired; consensus-based hierarchy creates high organizational costs and should only be adopted when the benefits for consensus are high, which is for problems that are highly complex and nondecomposable; finally, authority-based hierarchy is superior to markets in supporting heuristic search, but inferior in supporting directional search. The authors propose that authority basedhierarchies are best suitable for a range of problems that are moderately complex.

Nickerson and Zenger (2004) reasoning is an ingenious adaptation of fairly standard transaction cost economics. As such it relies on the notion of "discrete structural alternatives" (i.e., the three Williamsonian governance structures). In contrast, Grandori (1997, 2001a) analyzes the 
various kinds of governance mechanisms that govern the transfer, sharing and integration of knowledge between and within firms. She concludes that the portfolio of mechanisms that are effectively employable between firms to link nodes of specialized knowledge can hardly be distinguished from those mechanisms employable within firms. An implication of her discussion is a denial of the strong emphasis on discrete governance structures in transaction cost economics. This is exactly contrary to the thrust of the Nickerson and Zenger (2004) discussion which builds off the Williamsonian emphasis on discrete governance structures that embody fixed constellations of governance mechanisms. Through a series of practical examples of knowledge governance, Grandori argues that various kinds of governance mechanisms are typically not specific to governance structures. ${ }^{8}$

One future development path for knowledge governance lies in opting for higher microspecificity than is contained in the notion of governance structure. Governance structures can indeed contain different kinds of governing mechanisms in ways that may differ significantly across different manifestations of the "same" structure. This also means that it is hard to make clear prediction regarding how exactly governance structures drive knowledge processes. A more finegrained approach is to explore the various ways in which governance mechanisms combine to drive knowledge processes and what are the relations of complementarity and substitutability between governance mechanisms in this process. Such an undertaking will call on the skills and insights of organizational behaviour and human resource management scholars.

\section{THE FURTHER REACHES OF KNOWLEDGE GOVERNANCE: DEALING WITH} BOUNDED RATIONALITY AND ITS RAMIFICATIONS

\section{Epistemic and Cognitive Assumptions in Organizational Economics}

\footnotetext{
${ }^{8}$ The extent to which this is a critical point against, for example, transaction cost economics is open to debate. See, for example, Anderson and Gatignon (1986) for the same point, but made from the perspective of transaction cost economics.
} 
The conjecture that animates knowledge governance is that it is possible to bring knowledge considerations into the corpus of established organizational economics and organizational design in a "thick" manner, in the sense of dealing substantially with phenomena like tacit knowledge, differential capabilities and learning - phenomena that are not easily aligned with the standard economics paradigm of asymmetric and imperfect information.

However, such integration takes place on several levels. One is the level of empirical research where such integrative efforts may be a matter of throwing a couple of knowledge-related variables into otherwise entirely standard designs derived from, say, transaction cost economics. Another one is the level of theoretical inquiry. Here the situation is quite different. It is arguable that a concern with the role of knowledge in the context of economic organization may necessitate a reevaluation of a number of the fundamental assumptions that are often used to guide theorybuilding in the economics of organization (e.g., Bayesian and game theoretical foundations).

Organizational economics make strong assumptions about the cognitive powers of agents. Like virtually all of formal, mainstream economics, it assumes cognitive homogeneity, correctness, and constancy: agents hold the same, correct, model of the world, and that model does not change. These assumptions are built into formal contract theory (i.e., agency theory and property rights theory) through the assumption that payoffs, strategies, the structure of the game, and so on are common knowledge. Bounded rationality is occasionally invoked as a necessary part of the theory of the firm, particularly by Williamson $(1985,1996)$; but most of the contracting problems studied in the modern theory of the firm require only asymmetric information (Hart, 1990). Indeed, bounded rationality seems to serve little function beyond justifying the assumption that contracts are incomplete (Foss, 2001). Likewise, because of the Bayesian underpinning of game-theoretic contract theory, Knightian uncertainty, or any notion of open-endedness or indeterminacy, has no role to play. 
Because of these epistemic and cognitive assumptions, there is little or no role for governing knowledge in the wider sense of the governance of cognitive representations, including defining heuristics for dealing with Knightian uncertainty (Grandori, 2001b; 2011; Hatchuel, 2011). However, as Phelps (2006: 13) observes:

work on contracts has posited, explicitly or implicitly, that the parties to a contract share identical "rational expectations," since they have the identical model of the world. Work in that vein does not fit in a theory of capitalist economies, in which views are never homogenous and may be wildly diverse.

Demsetz (1988) argues that organizational economics suffers from a fundamental asymmetry: knowledge for the purpose of decision-making is assumed to be scarce (as in agency models with their reliance on asymmetric information), while knowledge for the purpose of production is free. Demsetz argues that taking scarce production knowledge into account implies a different theory of firm boundaries (roughly akin to what was discussed above as the capabilities view). However, the problem is deeper than Demsetz posits: Standard theories assume that knowledge may be costly, but decision-making is free in the sense that, equipped with sufficient knowledge, decision-makers can always compute an optimal solution to any decision problem. This is also reflected in the idea that differences in beliefs among individuals can be completely explained by differences in information and that individuals are not only (fully) rational in the sense of being capable of maximizing expected utility, but also ascribes such rationality to others These tenets are contradicted by the notion of bounded rationality and its various ramifications.

\section{Bounded Rationality and Economic Organization}

An important aspect of knowledge in the context of economic organization is bounded rationality, which not only speaks to the efficiency with which decision-makers process knowledge (Marschak \& Radner, 1972; Garicano, 2000), but also to issues of cognitive representations in 
complex and uncertain environments (Gavetti \& Levinthal, 2000; Grandori, 2001b; Hatchuel, 2001). Furubotn (2001: 136) explains that

[g]iven the cognitive restrictions that constrain each individual and the costly nature of information, a decision maker can have only partial knowledge of the full range of options known to the society as a whole. He can no longer be assumed to know everything about existing technological alternatives, the characteristics and availability of all productive inputs, the existence and true properties of every commodity in the system, etc.

In the context of the theory of the firm, we cannot reduce the relevant decision problem to combining known inputs into known outputs in a transaction cost minimizing manner. If decisionmakers know only a small subset of the many possible input combinations and cannot perfectly foresee future preferences, "the individual devising the firm's policies has to act as a true entrepreneur rather than as a manager routinely implementing clear-cut marginal rules for allocation." (Furubotn, 2001: 139). The formation of cognitive representation in the form of setting direction, defining missions and so on becomes crucial, as does making sure that a process of organizational learning takes place within this cognitive framework (Witt, 1998). Entrepreneurs also form cognitive representations about which assets they need to secure the services from, the major contractual hazards associated with such procurement, and the most effective ways of protecting against such hazards. This suggests that the same transaction might be governed very differently, as human agents may hold heterogeneous cognitive representations (see Argyres \& Liebeskind, 1999; Furubotn, 2002; Mayer \& Argyres, 2004).

Many proponents of bounded rationality have tended to model economic actors as hard-wired to choose certain courses of actions: "behavioralists tend to assume that agents are (1) hard-headed rule followers or (2) pre-programmed satisficers ab ovo" (Langlois \& Csontos, 1993: 118). Others 
have argued that Knightian uncertainty also has the effect of turning decision-makers into "hardheaded rule folloers" (e.g., Heiner, 1983). However, as Foss and Klein (this volume) argue, building on Knight (1921) and Mises (1949), there is a more positive side to bounded rationality and uncertainty, namely the formation of judgment. Judgment represents a novel conjecture regarding the use of resources for servicing preferences, resides in the head of an entrepreneur (or in the heads of the members of an entrepreneurial team), is difficult to communicate, and so on. This creates barriers to exchange, and to capture profit from his judgment the entrepreneur must deploy it in the context of his own venture, and hire employees who can work based on their derived judgment.

\section{Governing Cognitions}

Whereas the link in the Knightian story is from judgment to governance, governance also influences cognitions. Thus, Lindenberg (2003; see also Grandori [1997] and Lindenberg \& Foss, 2011) argues that the governance of motivation-for example, to share, create, integrate, etc. knowledge — is first and foremost the governance of cognition.

Lindenberg's argument fundamentally derives from bounded rationality, because with standard assumptions on cognition, there is fundamentally nothing to "govern" as individuals are cognitive alike. He applies the insight from (social) cognition research that mental constructs have to activated in order to affect behavior, and that goals are particularly important mental constructs in which cognitions and motivations are intricately intertwined (e.g., Kruglanski \& Köpetz, 2009), in the construction of a theory of "goal-framing." Briefly, overarching goals combine cognitive and motivational elements. When they are focal (i.e., when they are activated at the moment), such goals "frame" a situation by steering important cognitive processes in the service of the focal goal, a

process in which motivation expresses itself though cognitions. More concretely, goals (and especially overarching goals) govern what we attend to; what concepts and chunks of knowledge are being activated; what alternatives we consider; what information we are most sensitive about; 
and how we process information (Lindenberg \& Foss, 2011). For example, goals may be directed towards what is "appropriate" (the normative goal frame). Or, they may have hedonic orientations (the hedonic goal frame) or be oriented towards personal gain (the gain goal frame). Cues in the environment can drastically affect goals, thereby creating shifts in cognitions and motivations and the way they interact. Governance structures would have to be specifically constructed to deal with this interaction because it creates constraints on virtually all governance mechanisms.

Lindenberg and Foss (2011) systematically address how governance mechanisms affect goals. For example, they argue that authority structures that stress fiat or control rights as basis for the legitimacy of orders and instructions are likely to weaken the normative goal-frame in favor of a gain or hedonic goal-frame, and that group rewards that emphasize the contribution to common goals on a higher organizational level than the group itself support a normative goal-frame. Although this perspective is framed as a general one, applicable to all forms of organization, it is arguable that it is particularly applicable to the understanding of knowledge governance in organizations. The governance of knowledge raises distinct motivational, incentive and coordination problems in organizations, because of the difficulties of defining well-defined performance measures for knowledge sharing, integration, creation, and so on, and because of the importance of stimulating not just autonomously motivated behaviors, but, more specifically, behaviors that are intrinsically motivated (and thus conducive to creativity and learning) and socially motivated (and thus conducive to knowledge sharing efforts).

The goal framing perspective address different kinds of motivation, deriving from different cognitions, that are all in different ways important to knowledge governance. In particular, the perspective recognizes that undertaking different kinds of knowledge-related efforts require different motivations, and therefore different governance instruments. Thus, creative, knowledgecreating behaviors may require a dominance of hedonic goal-frames are associated with intrinsic 
motivations, while the sharing of knowledge may require the dominance of the normative goal frame that is more strongly associated with pro-social motivations.

\section{CONCLUSIONS}

In this chapter I have provided characterization of the emerging field of knowledge, differentiating between two knowledge governance streams: A stream that endogenizes knowledge and identifies governance structures and mechanisms as relevant antecedents, and a stream that reverses this causality. The former stream owes much to certain currents in the theory of the firm, notably team theory and transaction cost economics, and to contributions to management research in organization, strategic alliances, product development and international business. The latter stream owes more to the capabilities view of the firm. This interpretation and account complements earlier accounts of knowledge governance, notably Grandori and Kogut (2002) and Foss (2007). To progress, however, the knowledge governance view needs to go beyond the notions of agency, motivation and cognition associated with its source theory. In particular, knowledge governance ultimately means more than the efficient organization of knowledge-related transactions, activities or behaviours: It also means governing the cognitions of individuals, and therefore the knowledge that is pragmatically applied to make sense out of situations and what should properly be done in those situations. Although the knowledge governance approach has historically developed from the economic theory of the firm, organizational design perspectives, the capabilities view, and knowledge management, in the future knowledge governance will benefit from closer liaisons with cognitive science and the micro organizational behaviour literature. 


\section{REFERENCES}

Adler, P. S. 2001. Market, hierarchy, and trust: The knowledge economy and the future of capitalism. Organization Science, 12: 215-234.

Alchian, A. A. 1984. Specificity, specialization, and coalitions. Journal of Institutional and Theoretical Economics, 140: 34-49.

Alchian, A. A. and Demsetz, H. 1972. Production, Information Costs, and Economic Organization. American Economic Review 62: 772-795.

Anderson, E. and Gatignon, H. 1986. Modes of Foreign Entry: A Transaction Cost Analysis and Propositions. Journal of International Business Studies, Vol. 17, No. 3 (Autumn, 1986), pp. $1-26$

Argote, L. and Ingram, P. 2000. Knowledge Transfer: A Basis for Competitive Advantage in Firms. Organizational Behavior and Human Decision Processes, 82(1): 150-169.

Argyres, N. 1996. Evidence on the Role of Firm Capabilities in Vertical Integration Decisions. Strategic Management Journal, 17: 129-150.

Argyres, N. S. and Liebeskind, J. P. 1999. Contractual Commitments, Bargaining Power, and Governance Inseparability: Incorporating History into Transaction Cost Theory. Academy of Management Review 24(1): 49-63.

Argyres, N. S. and Mayer, K. J. 2007. Contract Design as a Firm Capability: An Integration of Learning and Transaction Cost Perspectives. Academy of Management Review 32: 1060-77.

Argyres, N., Felin, T., Foss, N. J. and Zenger, T. 2011. The Organizational Economics of Organizational Capability and Heterogeneity: A Research Agenda. Organization Science (forthcoming).

Barzel, Y. 1997. Economic Analysis of Property Rights. Cambridge: Cambridge University Press.

Child, J. and McGrath, R. 2001. Organizations Unfettered: Organizational Form in an Information Intensive Economy. Academy of Management Journal 44: 1135-1148.

Coase, R. H. 1937 The Nature of the Firm. Economica 4: 386-405.

Coase, R. H. 1960. The Problem of Social Cost. Journal of Law and Economics 3: 1-44.

Coff, R. 1999. When Competitive Advantage Doesn't Lead to Performance: Resource-based Theory and Stakeholder Bargaining Power. Organization Science 10: 119-133, 1999

Coff, R. and Blyler, M. 2003. Dynamic Capabilities, Social Capital, and Rent Appropriation: Ties that Split Pies. Strategic Management Journal 24: 677-686.

Connor, K. R. and Prahalad, C. K. 1996. A Resource-Based Theory of the Firm: Knowledge versus Opportunism. Organization Science, 7, 5: 477-501.

Contractor, F. J. and Ra, W. 2002. How Knowledge Attributes Influence Alliance Governance Choices. Journal of International Management 8: 11-27.

Easterby-Smith, M. and Lyles, M. A. eds. 2003. Handbook of Organizational Learning and Knowledge Management. Oxford: Blackwell Publishing. 
Eisenhardt, K. M. and Santos, F. M. 2003. Knowledge-based view: A New View of Strategy. In Pettigrew, A., Thomas, H. and Whittington, R. eds. Handbook of Strategy and Management. London: Sage.

Foss, N. J. 2001. Leadership, Beliefs and Coordination. Industrial and Corporate Change 10: $357-$ 388.

Foss, N. J. 2007. The Emerging Knowledge Governance Approach. Organization, 14: 29-52.

Foss, N. J. \& Mahnke, V. 2003. Knowledge Management: What Does Organizational Economics Contribute? In Easterby-Smith, M. and Lyles, M. eds. Handbook of Knowledge Management. Oxford: Basil Blackwell.

Foss, N. J., Minbaeva, D. B., Pedersen, T., \& Reinholt, M. 2009. Encouraging knowledge sharing among employees: How job design matters. Human Resource Management, 48(6): 871-893.

Foss, N. J., and Lindenberg, S. 2011. Teams, Team Agency, and the Theory of the Firm. Managerial and Decision Economics (forthcoming).

Foss, N. J., Laursen, K. and Pedersen, T. 2011. Linking Customer Interaction and Innovation: The Mediating Role of New Organizational Practices. Organization Science forthcoming.

Foss, N. J. and Stea, D. The Principal's Theory of Mind. Working Paper.

Furubotn, E. G. 2001. The New Institutional Economics and the Theory of the Firm. Journal of Economics Behavior and Organization 45(2): 133-53.

Furubotn, E. G. 2002. Entrepreneurship, Transaction-Cost Economics, and the Design of Contracts. In Brousseau, E. and Glachant, J. M. eds. The Economics of Contracts: Theories and Applications. Cambridge: Cambridge University Press.

Garicano, L. 2000. Hierarchies and the Organization of Knowledge in Production. Journal of Political Economy, 108(5): 874-904.

Gavetti, G. and Levinthal, D. 2000. Looking Forward and Looking Backward: Cognitive and Experiential Search. Administrative Science Quarterly 45(1): 113-37.

Ghoshal, S., Moran, P. and Almeida-Costa, L. 1995. The Essence of the Megacorporation: Shared Context, Not Structural Hierarchy. Journal of Institutional and Theoretical Economics 151: 748-59.

Ghoshal S. and Tsai, W. 1998. Social capital and value creation: the role of intra-firm networks. Academy of Management Journal 41: 464-476.

Goldman, A. J. 1978. Epistemics: The regulative theory of cognition. The Journal of Philosophy, 75: 509-23.

Gottschalg O. and Zollo M., 2007 Interest alignment and competitive advantage. Academy of Management Review 32(2): 418-437.

Grandori, A. 1997. Governance Structures, Coordination Mechanisms and Cognitive Models. Journal of Management and Governance 1: 29-42.

Grandori, A. 2001a. Neither Hierarchy nor Identity: Knowledge Governance Mechanisms and the Theory of the Firm. Journal of Management and Governance 5: 381-399.

Grandori, A. 2001b. 'Cognitive Failures' and Combinative Governance. Journal of Management and Governance 1: 252-260. 
Grandori, A. 2011. A Rational Heuristic Model of Economic Decision Making. Rationality and Society (forthcoming).

Grandori, A. and Kogut, B. 2002. Dialogue on Organization and Knowledge. Organization Science 13: $224-232$.

Granovetter, M. S. 1973 The strength of weak ties. American Journal of Sociology 78 (May): 13601380.

Grant, R. M. 1996. Towards a Knowledge-based Theory of the Firm. Strategic Management Journal 17: 109-122.

Hart, O. D. 1995. Firms, Contracts, and Financial Structure. Oxford: Oxford University Press.

Hart, O. D. 1990. Is 'Bounded Rationality' an Important Element of a Theory of Institutions? Journal of Institutional and Theoretical Economics 16: 696-702.

Hatchuel, A. 2001. Towards Design Theory and Expandable Rationality: The Unfinished Program of Herbert Simon. Journal of Management and Governance, 5: 260-273

Heiner, R. A. 1983. The Origin of Predictable Behavior. American Economic Review, 73, 560-95.

Heiman, B. and Nickerson, J. A. 2002. Towards Reconciling Transaction Cost Economics and the Knowledge-based View of the Firm: The Context of Interfirm Collaborations. International Journal of the Economics of Business 9: 97-116.

Holmström, B. and Roberts, J. 1998. Boundaries of the Firm Revisited. Journal of Economic Perspectives, 12: 73-94.

Jacobides, M. G. and Winter, S. G. 2005. The co-evolution of capabilities and transaction costs: Explaining the institutional structure of production. Strategic Management Journal 26(5): 395-413.

Jensen, M. C. and Meckling, W. H. 1992. Specific and General Knowledge, and Organizational Structure. In Werin, L. and Wijkander, H. eds., Contract Economics. Oxford: Blackwell.

Jones, G. R. 1983. Transaction Costs, Property Rights, and Organizational Culture: An Exchange Perspective. Administrative Science Quarterly 28: 454-467.

Kauffman, S. 1995. At Home in the Universe, Oxford: Oxford University Press.

Knight, F. H. 1921. Risk, Uncertainty, and Profit. New York: August M. Kelley.

Kogut, B. and Zander, U. 1992. Knowledge of the Firm, Combinative Capabilities, and the Replication of Technology. Organization Science 3: 383-397.

Kogut, B. and Zander, U. 1993. Knowledge of the Firm and the Evolutionary Theory of the Multinational Corporation. Journal of International Business Studies 24: 625-645.

Kogut, B. and Zander, U. 1996. What Firms Do? Coordination, Identity, and Learning. Organization Science 7: 502-518.

Kogut, B. 2000. The Network as Knowledge: Generative Rules and the Emergence of Structure. Strategic Management Journal 21: 405-425.

Kruglanski, A. W. and Köpetz, C. 2009. What is so special (and non-special) about goals? A view from the cognitive perspective. In Moskowitz, G. B. and Grant, H. eds. The Psychology of Goals. New York: Guilford Press 
Langlois, R. N. 1988. Economic Change and the Boundaries of the Firm. Journal of Institutional and Theoretical Economics 144: 635-657.

Langlois, R. N. 1992. Transaction Cost Economics in Real Time. Industrial and Corporate Change 1(1): 99-127.

Langlois, R. N. 2003. The Vanishing Hand: The Changing Dynamics of Industrial Capitalism. Industrial and Corporate Changes 12(2): 351-385.

Langlois, R.N. 2007. The Entrepreneurial Theory of the Firm and the Theory of the Entrepreneurial Firm. Journal of Management Studies, 44: 1107-1124.

Langlois, R. N. and Csontos, L. 1993. Optimization, Rule-Following, and the Methodology of Situational Analysis. In Mäki, U., Gustafsson, B. and Knudsen, C. eds. 1993. Rationality, Institutions, and Economic Methodology. London: Routledge.

Langlois, R. N., and Robertson, P. L. 1995. Firms, Markets, and Economic Change: A Dynamic Theory of Business Institutions. London: Routledge.

Langlois, R. N. and Foss, N. J. 1999. Capabilities and Governance: the Rebirth of Production in the Theory of Economic Organization. KYKLOS 52: 201-218.

Lindenberg, S. 2003. The Cognitive Side of Governance. Research in the Sociology of Organizations 20: 47-76.

Madhok A. 1996. The organization of economic activity: transaction costs, firm capabilities and the nature of governance. Organization Science 7: 577-590.

Mahoney, J. and Pandian, J. R. 1992. The resource-based view within the conversation of strategic management. Strategic Management Journal, 13: 363-380

Maritan, C.A. and Brush, T. H. 2003. Heterogeneity and Transferring Practices: Implementing Flow Manufacturing in Multiple Plants. Strategic Management Journal 24: 945-960.

Marschak, J., and Radner, R. 1972. The Economic Theory of Teams. New Haven: Cowles Foundation and Yale University Press.

Mayer, K. and Argyres, N. 2004. Learning to Contract. Organization Science 15: 394-410.

Minbaeva, D., Pedersen, T., Björkman, I., Fey, C. and Park, H. J. 2003. MNC Knowledge Transfer, Subsidiary Absorptive Capacity, and HRM. Journal of International Business Studies 34: 586-599.

Mises, L. von. 1949. Human Action: A Treatise on Economics. New Haven: Yale University Press.

Mowery, D. C., Oxley, J. and Silverman, B. 1996. Strategic Alliances and Interfirm Knowledge Transfer. Strategic Management Journal 17: 77-91.

Nelson, R. R. and Winter, S. G. 1982. The Evolutionary Theory of the Firm. Cambridge, MA: Harvard University Press.

Nickerson, J. and Zenger, T. 2004. A Knowledge-based Theory of the Firm: The Problem-Solving Perspective. Organization Science 15(6): 617-632

Osterloh, M. and Frey, B. 2000. Motivation, Knowledge Transfer and Organizational Form. Organization Science 11: 538-550.

Oxley, J. 1997. Appropriability Hazards and Governance in Strategic Alliances: a Transaction Cost Approach. Journal of Law, Economics, and Organization 13: 387-409. 
Penrose, E. T. 1959. The Theory of the Growth of the Firm. Oxford: Blackwell.

Phelps, E. P. 2006. Further Steps to a Theory of Innovation and Growth - On the Path Begun by Knight, Hayek, and Polanyí. Paper for the 2006 ASSA meetings.

Reinholt, M., Pedersen, T. and Foss, N. J. 2012. Why a Central Network Position Isn't Enough: the Role of Motivation and Ability for Knowledge Sharing in Networks. Academy of Management Journal (forthcoming).

Richardson, G.B. 1972. The Organisation of Industry. The Economic Journal: 883-896.

Sah R. and Stiglitz, J. E. 1985. The Theory of Economic Organizations, Human Fallibility and Economic Organization. American Economic Review, Papers and Proceedings 75: 292-297.

Sah R. and Stiglitz, J. E. 1986. The Architecture of Economic Systems: Hierarchies and Polyarchies. American Economic Review 76: 716-727.

Silverman, B.S. 1999. Technological Resources and the Direction of Corporate Diversification: Toward an Integration of Transaction Cost Economics and the Resource-Based View. Management Science, August: 1109-1124

Simon, H. A. 1962. The Architecture of Complexity. Proceedings of the American Philosophical Society 106: 467-82.

Simonin, B. L. 1999. Transfer of Marketing Know-How in International Strategic Alliances. Journal of International Business Studies 30: 463-490.

Spender, J.C. 1996. Making Knowledge the Basis of a Dynamic Theory of the Firm. Strategic Management Journal 17 (Winter special issue): 45-62.

Spender, J.C. 2005. Review Article: An Essay of the State of Knowledge Management. Prometheus 23(1): 101-116.

Starbuck, W. 1992. Learning by Knowledge-Intensive Firms. Journal of Management Studies 29: 713-41.

Tallman, S. 2003. The Significance of Bruce Kogut's and Udo Zander's Article, 'Knowledge of the Firm and the Evolutionary Theory of the Multinational Morporation'. Journal of International Business Studies 34: 495-497.

Teece, D.J. 1977. Technology Transfer by Multinational Firms: The Resource Costs of Transferring Technological Know-How. Economic Journal: 242-261.

Teece, D. J. 2003. Expert Talent and the Design of (Professional Services) Firms, Industrial and Corporate Change 12: 895-916.

Teece, D. J., Pisano, G. and Shuen, A. 1997. Dynamic Capabilities and Strategic Management. Strategic Management Journal 18: 509-534.

Tsai, W. P. 2001. Knowledge Transfer in Intra-organizational Networks. Academy of Management Journal 44(5): 996-1004

Tsai, W. P. 2002. Social Structure of 'Coopetition' within a Multiunit Organization. Organization Science 13: 179-190

Williamson, O. E. 1985. The Economic Institutions of Capitalism. New York: Free Press.

Williamson, O. E. 1996. The Mechanisms of Governance. Oxford: Oxford University Press. 
Williamson, O. E. 1999. Strategy research: Governance and competence perspectives. Strategic Management Journal, 20: 1087-1108.

Williamson, O. E. and Riordan. M. 1985. Asset specificity and economic organization. International Journal of Industrial Organization 36: 5-378.

Williamson, O. E., Wachter, M. L. and Harris, J. E. 1975. Understanding the Employment Relation: The Analysis of Idiosyncratic Exchange. Bell Journal of Economics $6: 250-278$.

Winter, S. G. 1987. Knowledge and Competence as Strategic Assets. In Teece, D. ed., 159-184, The Competitive Challenge. Cambridge, MA: Ballinger.

Winter, S. G. 1988. On Coase, Competence, and the Corporation. Journal of Law, Economics, and Organization 4(1): 163-80.

Zenger, T. R., \& Hesterly, W. S. 1997. The disaggregation of U.S. corporations: Selective intervention, high-powered incentives, and molecular units. Organization Science, 8: 209222.

Zingales, L. 2000. In Search of New Foundations. Journal of Finance, 55: 1623- 1653

Zucker, L. G. 1991. Postscript: microfoundations of institutional thought. In Powell, W. W. and DiMaggio, P. J. (eds) The New Institutionalism in Organisational Analysis, Chicago, IL: University of Chicago Press. 


\section{SMG - Working Papers \\ www.cbs.dk/smg \\ 2003}

2003-1: Nicolai J. Foss, Kenneth Husted, Snejina Michailova, and Torben Pedersen: Governing Knowledge Processes: Theoretical Foundations and Research Opportunities.

2003-2: Yves Doz, Nicolai J. Foss, Stefanie Lenway, Marjorie Lyles, Silvia Massini, Thomas P. Murtha and Torben Pedersen: Future Frontiers in International Management Research: Innovation, Knowledge Creation, and Change in Multinational Companies.

2003-3: Snejina Michailova and Kate Hutchings: The Impact of In-Groups and OutGroups on Knowledge Sharing in Russia and China CKG Working Paper.

2003-4: Nicolai J. Foss and Torben Pedersen: The MNC as a Knowledge Structure: The Roles of Knowledge Sources and Organizational Instruments in MNC Knowledge Management CKG Working Paper.

2003-5: Kirsten Foss, Nicolai J. Foss and Xosé H. Vázquez-Vicente: “Tying the Manager's Hands": How Firms Can Make Credible Commitments That Make Opportunistic Managerial Intervention Less Likely CKG Working Paper.

2003-6: Marjorie Lyles, Torben Pedersen and Bent Petersen: Knowledge Gaps: The Case of Knowledge about Foreign Entry.

2003-7: Kirsten Foss and Nicolai J. Foss: The Limits to Designed Orders: Authority under "Distributed Knowledge" CKG Working Paper.

2003-8: Jens Gammelgaard and Torben Pedersen: Internal versus External Knowledge Sourcing of Subsidiaries - An Organizational Trade-Off.

2003-9: Kate Hutchings and Snejina Michailova: Facilitating Knowledge Sharing in Russian and Chinese Subsidiaries: The Importance of Groups and Personal Networks Accepted for publication in Journal of Knowledge Management.

2003-10: Volker Mahnke, Torben Pedersen and Markus Verzin: The Impact of Knowledge Management on MNC Subsidiary Performance: the Role of Absorptive Capacity CKG Working Paper.

2003-11: Tomas Hellström and Kenneth Husted: Mapping Knowledge and Intellectual Capital in Academic Environments: A Focus Group Study Accepted for publication in Journal of Intellectual Capital CKG Working Paper.

2003-12: Nicolai J Foss: Cognition and Motivation in the Theory of the Firm: Interaction or "Never the Twain Shall Meet"? Accepted for publication in Journal des Economistes et des Etudes Humaines CKG Working Paper.

2003-13: Dana Minbaeva and Snejina Michailova: Knowledge Transfer and Expatriation Practices in MNCs: The Role of Disseminative Capacity.

2003-14: Christian Vintergaard and Kenneth Husted: Enhancing Selective Capacity Through Venture Bases. 


\section{4}

2004-1: Nicolai J. Foss: Knowledge and Organization in the Theory of the Multinational Corporation: Some Foundational Issues

2004-2: Dana B. Minbaeva: HRM Practices and MNC Knowledge Transfer

2004-3: Bo Bernhard Nielsen and Snejina Michailova: Toward a Phase-Model of Global Knowledge Management Systems in Multinational Corporations

2004-4: Kirsten Foss \& Nicolai J Foss: The Next Step in the Evolution of the RBV: Integration with Transaction Cost Economics

2004-5: Teppo Felin \& Nicolai J. Foss: Methodological Individualism and the Organizational Capabilities Approach

2004-6: Jens Gammelgaard, Kenneth Husted, Snejina Michailova: Knowledge-sharing Behavior and Post-acquisition Integration Failure

2004-7: Jens Gammelgaard: Multinational Exploration of Acquired R\&D Activities

2004-8: Christoph Dörrenbächer \& Jens Gammelgaard: Subsidiary Upgrading? Strategic Inertia in the Development of German-owned Subsidiaries in Hungary

2004-9: Kirsten Foss \& Nicolai J. Foss: Resources and Transaction Costs: How the Economics of Property Rights Furthers the Resource-based View

2004-10: Jens Gammelgaard \& Thomas Ritter: The Knowledge Retrieval Matrix: Codification and Personification as Separate Strategies

2004-11: Nicolai J. Foss \& Peter G. Klein: Entrepreneurship and the Economic Theory of the Firm: Any Gains from Trade?

2004-12: Akshey Gupta \& Snejina Michailova: Knowledge Sharing in Knowledge-Intensive Firms: Opportunities and Limitations of Knowledge Codification

2004-13: Snejina Michailova \& Kate Hutchings: Knowledge Sharing and National Culture: A Comparison Between China and Russia

\section{5}

2005-1: Keld Laursen \& Ammon Salter: My Precious - The Role of Appropriability Strategies in Shaping Innovative Performance

2005-2: Nicolai J. Foss \& Peter G. Klein: The Theory of the Firm and Its Critics: A Stocktaking and Assessment

2005-3: Lars Bo Jeppesen \& Lars Frederiksen: Why Firm-Established User Communities Work for Innovation: The Personal Attributes of Innovative Users in the Case of Computer-Controlled Music

2005-4: Dana B. Minbaeva: Negative Impact of HRM Complementarity on Knowledge Transfer in MNCs

2005-5: Kirsten Foss, Nicolai J. Foss, Peter G. Klein \& Sandra K. Klein: Austrian Capital 
Theory and the Link Between Entrepreneurship and the Theory of the Firm

2005-1: Nicolai J. Foss: The Knowledge Governance Approach

2005-2: Torben J. Andersen: Capital Structure, Environmental Dynamism, Innovation Strategy, and Strategic Risk Management

2005-3: Torben J. Andersen: A Strategic Risk Management Framework for Multinational Enterprise

2005-4: Peter Holdt Christensen: Facilitating Knowledge Sharing: A Conceptual Framework

2005-5 Kirsten Foss \& Nicolai J. Foss: Hands Off! How Organizational Design Can Make Delegation Credible

2005-6 Marjorie A. Lyles, Torben Pedersen \& Bent Petersen: Closing the Knowledge Gap in Foreign Markets - A Learning Perspective

2005-7 Christian Geisler Asmussen, Torben Pedersen \& Bent Petersen: How do we Capture "Global Specialization" when Measuring Firms' Degree of internationalization?

2005-8 Kirsten Foss \& Nicolai J. Foss: Simon on Problem-Solving: Implications for New Organizational Forms

2005-9 Birgitte Grøgaard, Carmine Gioia \& Gabriel R.G. Benito: An Empirical Investigation of the Role of Industry Factors in the Internationalization Patterns of Firms

2005-10 Torben J. Andersen: The Performance and Risk Management Implications of Multinationality: An Industry Perspective

2005-11 Nicolai J. Foss: The Scientific Progress in Strategic Management: The case of the Resource-based view

2005-12 Koen H. Heimeriks: Alliance Capability as a Mediator Between Experience and Alliance Performance: An Empirical Investigation Into the Alliance Capability Development Process

2005-13 Koen H. Heimeriks, Geert Duysters \& Wim Vanhaverbeke: Developing Alliance Capabilities: An Empirical Study

2005-14 JC Spender: Management, Rational or Creative? A Knowledge-Based Discussion

\section{6}

2006-1: Nicolai J. Foss \& Peter G. Klein: The Emergence of the Modern Theory of the Firm

2006-2: Teppo Felin \& Nicolai J. Foss: Individuals and Organizations: Thoughts on a Micro-Foundations Project for Strategic Management and Organizational Analysis

2006-3: Volker Mahnke, Torben Pedersen \& Markus Venzin: Does Knowledge Sharing 
Pay? An MNC Subsidiary Perspective on Knowledge Outflows

2006-4: Torben Pedersen: Determining Factors of Subsidiary Development

2006-5 Ibuki Ishikawa: The Source of Competitive Advantage and Entrepreneurial Judgment in the RBV: Insights from the Austrian School Perspective

2006-6 Nicolai J. Foss \& Ibuki Ishikawa: Towards a Dynamic Resource-Based View: Insights from Austrian Capital and Entrepreneurship Theory

2006-7 Kirsten Foss \& Nicolai J. Foss: Entrepreneurship, Transaction Costs, and Resource Attributes

2006-8 Kirsten Foss, Nicolai J. Foss \& Peter G. Klein: Original and Derived Judgement: An Entrepreneurial Theory of Economic Organization

2006-9 Mia Reinholt: No More Polarization, Please! Towards a More Nuanced Perspective on Motivation in Organizations

2006-10 Angelika Lindstrand, Sara Melen \& Emilia Rovira: Turning social capital into business? A study of Swedish biotech firms' international expansion

2006-11 Christian Geisler Asmussen, Torben Pedersen \& Charles Dhanaraj: Evolution of Subsidiary Competences: Extending the Diamond Network Model

2006-12 John Holt, William R. Purcell, Sidney J. Gray \& Torben Pedersen: Decision Factors Influencing MNEs Regional Headquarters Location Selection Strategies

2006-13 Peter Maskell, Torben Pedersen, Bent Petersen \& Jens Dick-Nielsen: Learning Paths to Offshore Outsourcing - From Cost Reduction to Knowledge Seeking

2006-14 Christian Geisler Asmussen: Local, Regional or Global? Quantifying MNC Geographic Scope

2006-15 Christian Bjørnskov \& Nicolai J. Foss: Economic Freedom and Entrepreneurial Activity: Some Cross-Country Evidence

2006-16 Nicolai J. Foss \& Giampaolo Garzarelli: Institutions as Knowledge Capital: Ludwig M. Lachmann's Interpretative Institutionalism

2006-17 Koen H. Heimriks \& Jeffrey J. Reuer: How to Build Alliance Capabilities

2006-18 Nicolai J. Foss, Peter G. Klein, Yasemin Y. Kor \& Joseph T. Mahoney: Entrepreneurship, Subjectivism, and the Resource - Based View: Towards a New Synthesis

2006-19 Steven Globerman \& Bo B. Nielsen: Equity Versus Non-Equity International Strategic Alliances: The Role of Host Country Governance

\section{7}

2007-1 Peter Abell, Teppo Felin \& Nicolai J. Foss: Building Micro-Foundations for the Routines, Capabilities, and Performance Links 
2007-2 Michael W. Hansen, Torben Pedersen \& Bent Petersen: MNC Strategies and Linkage Effects in Developing Countries

2007-3 Niron Hashai, Christian G. Asmussen, Gabriel R.G. Benito \& Bent Petersen: Predicting the Diversity of Foreign Entry Modes

2007-4 Peter D. Ørberg Jensen \& Torben Pedersen: Whether and What to Offshore?

2007-5 Ram Mudambi \& Torben Pedersen: Agency Theory and Resource Dependency Theory: Complementary Explanations for Subsidiary Power in Multinational Corporations

2007-6 Nicolai J. Foss: Strategic Belief Management

2007-7 Nicolai J. Foss: Theory of Science Perspectives on Strategic Management Research: Debates and a Novel View

2007-8 Dana B. Minbaeva: HRM Practices and Knowledge Transfer in MNCs

2007-9 Nicolai J. Foss: Knowledge Governance in a Dynamic Global Context: The Center for Strategic Management and Globalization at the Copenhagen Business School

2007-10 Paola Gritti \& Nicolai J. Foss: Customer Satisfaction and Competencies: An Econometric Study of an Italian Bank

2007-11 Nicolai J. Foss \& Peter G. Klein: Organizational Governance

2007-12 Torben Juul Andersen \& Bo Bernhard Nielsen: The Effective Ambidextrous Organization: A Model of Integrative Strategy Making Processes.

\section{8}

2008-1 Kirsten Foss \& Nicolai J. Foss: Managerial Authority When Knowledge is Distributed: A Knowledge Governance Perspective

2008-2 Nicolai J. Foss: Human Capital and Transaction Cost Economics.

2008-3 Nicolai J. Foss \& Peter G. Klein: Entrepreneurship and Heterogeneous Capital.

2008-4 Nicolai J. Foss \& Peter G. Klein: The Need for an Entrepreneurial Theory of the Firm.

2008-5 Nicolai J. Foss \& Peter G. Klein: Entrepreneurship: From Opportunity Discovery to Judgment.

2008-6 Mie Harder: How do Rewards and Management Styles Influence the Motivation to Share Knowledge?

2008-7 Bent Petersen, Lawrence S. Welch \& Gabriel R.G. Benito: Managing the Internalisation Process - A Theoretical Perspective.

2008-8 Torben Juul Andersen: Multinational Performance and Risk Management Effects: Capital Structure Contingencies. 
2008-9 Bo Bernard Nielsen: Strategic Fit and the Role of Contractual and Procedural Governance in Alliances: A Dynamic Perspective.

2008-10 Line Gry Knudsen \& Bo Bernhard Nielsen: Collaborative Capability in R\&D Alliances: Exploring the Link between Organizational and Individual level Factors.

2008-11 Torben Juul Andersen \& Mahesh P. Joshi: Strategic Orientations of Internationalizing Firms: A Comparative Analysis of Firms Operating in Technology Intensive and Common Goods Industries.

2008-12 Dana Minbaeva: HRM Practices Affecting Extrinsic and Intrinsic Motivation of Knowledge Receivers and their Effect on Intra-MNC Knowledge Transfer.

2008-13 Steen E. Navrbjerg \& Dana Minbaeva: HRM and IR in Multinational Corporations: Uneasy Bedfellows?

2008-14 Kirsten Foss \& Nicolai J. Foss: Hayekian Knowledge Problems in Organizational Theory.

2008-15 Torben Juul Andersen: Multinational Performance Relationships and Industry Context.

2008-16 Larissa Rabbiosi: The Impact of Subsidiary Autonomy on MNE Knowledge Transfer: Resolving the Debate.

2008-17 Line Gry Knudsen \& Bo Bernhard Nielsen: Organizational and Individual Level Antecedents of Procedural Governance in Knowledge Sharing Alliances.

2008-18 Kirsten Foss \& Nicolai J. Foss: Understanding Opportunity Discovery and Sustainable Advantage: The Role of Transaction Costs and Property Rights.

2008-19 Teppo Felin \& Nicolai J. Foss: Social Reality, The Boundaries of Self-fulfilling Prophecy, and Economics.

2008-20 Yves Dos, Nicolai J. Foss \& José Santos: A Knowledge System Approach to the Multinational Company: Conceptual Grounding and Implications for Research

2008-21 Sabina Nielsen \& Bo Bernhard Nielsen: Why do Firms Employ foreigners on Their Top Management Teams? A Multi-Level Exploration of Individual and Firm Level Antecedents

2008-22 Nicolai J. Foss: Review of Anders Christian Hansen's “Uden for hovedstrømmen - Alternative strømninger i økonomisk teori"

2008-23 Nicolai J. Foss: Knowledge, Economic Organization, and Property Rights

2008-24 Sjoerd Beugelsdijk, Torben Pedersen \& Bent Petersen: Is There a Trend Towards Global Value Chain Specialization? - An Examination of Cross Border Sales of US Foreign Affiliates 
2008-25 Vikas Kumar, Torben Pedersen \& Alessandro Zattoni: The performance of business group firms during institutional transition: A longtitudinal study of Indian firms

2008-26 Sabina Nielsen \& Bo B. Nielsen: The effects of TMT and Board Nationality Diversity and Compensation on Firm Performance

2008-27 Bo B. Nielsen \& Sabina Nielsen: International Diversification Strategy and Firm Performance: A Multi-Level Analysis of Firm and Home Country Effects

\section{9}

2009-1 Nicolai J. Foss: Alternative Research Strategies in the Knowledge Movement: From Macro Bias to Micro-Foundations and Multi-Level Explanation

2009-2 Nicolai J. Foss \& Peter G. Klein: Entrepreneurial Alertness and Opportunity Discovery: Origins, Attributes, Critique

2009-3 Nicolai J. Foss \& Dana B. Minbaeva: Governing Knowledge: The Strategic Human Resource Management Dimension

2009-4 Nils Stieglitz \& Nicolai J. Foss: Opportunities and New Business Models: Transaction Cost and Property Rights Perspectives on Entrepreneurships

2009-5 Torben Pedersen: Vestas Wind Systems A/S: Exploiting Global R\&D Synergies

2009-6 Rajshree Agarwal, Jay B. Barney, Nicolai J. Foss \& Peter G. Klein: Heterogeneous Resources and the Financial Crisis: Implications of Strategic Management Theory

2009-7 Jasper J. Hotho: A Measure of Comparative Institutional Distance

2009-8 Bo B. Nielsen \& Sabina Nielsen: The Impact of Top Management Team Nationality Diversity and International Experience on Foreign Entry Mode

2009-9 Teppo Felin \& Nicolai Juul Foss: Experience and Repetition as Antecedents of Organizational Routines and Capabilities: A Critique of Behaviorist and Empiricist Approaches

2009-10 Henk W. Volberda, Nicolai J. Foss \& Marjorie E. Lyles: Absorbing the Concept of Absorptive Capacity: How To Realize Its Potential in the Organization Field

2009-11 Jan Stentoft Arlbjørn, Brian Vejrum Wæhrens, John Johansen \& Torben Pedersen: Produktion i Danmark eller offshoring/outsourcing: Ledelsesmæssige udfordringer 


\section{0}

2010-1 Dana B. Minbaeva, Kristiina Mäkelä \& Larissa Rabbiosi: Explaining Intraorganizational Knowledge Transfer at the Individual Level

2010-2 Dana B.Minbaeva \& Torben Pedersen: Governing Individual Knowledge Sharing Behavior

2010-3 Nicolai J. Foss \& Peter G. Klein: Alertness, Judgment, and the Antecedents of Entrepreneurship

2010-4 Nicolai J.Foss \& Joseph T.Mahoney: Exploring Knowledge Governance

2010-5 Jasper J. Hotho, Florian Becker-Ritterspach \& Ayse Saka-Helmhout: Enriching Absorptive Capacity Through Social Interaction

2010-6 Nicolai J. Foss \& Bo B. Nielsen: Researching Collaborative Advantage: Some Conceptual and Multi-level Issues

2010-7 Nicolai J. Foss \& Nils Stieglitz: Modern Resource-Based Theory(ies)

2010-8 Christian Bjørnskov \& Nicolai J. Foss: Do Economic Freedom and Entrepreneurship Impact Total Factor Productivity?

2010-9 Gabriel R.G. Benito, Bent Petersen \& Lawrence S. Welch: Mode Combinations and International Operations: Theoretical Issues and an Empirical Investigation

\section{1}

2011-1 Peter D. Ørberg Jensen \& Bent Petersen: Human Asset Internalization and Global Sourcing of Services - A Strategic Management Analysis on Activity-level

2011-2 Mie Harder: Management Innovation Capabilities: A Typology and Propositions for Management Innovation Research

2011-3 Mie Harder: Internal Antecedents of Management Innovation: The effect of diagnostic capability and implementation capability 
2011-4 Mie Harder: Explaining Management Innovation Pervasiveness: The Role of Internal Antecedents

2011-5 Mie Harder: Internal Determinants of Product Innovation and Management Innovation: The Effect of Diagnostic Capability and Implementation Capability

2011-6 Nicolai J. Foss, Peter G. Klein \& Per L. Bylund: Entrepreneurship and the Economics of the Firm

2011-7 Nicolai J. Foss \& Jacob Lyngsie: The Emerging Strategic Entrepreneurship Field: Origins, Key Tenets and Research Gaps

2011-8 Nicolai J. Foss: Entrepreneurship in the Context of the Resource-based View of the Firm

2011-9 Bent Petersen, Gabriel R.G. Benito, Olesya Dovgan, Lawrence Welch: Offshore outsourcing: A dynamic, operation mode perspective

2011-10 Bent Petersen, Gabriel R. G. Benito \& Lawrence Welch: Dynamics of Foreign Operation Modes and their Combinations: Insights for International Strategic Management

2011-11 Nicolai J. Foss: Teams, Team Motivation, and the Theory of the Firm

2011-12 Nicolai J. Foss: Knowledge Governance: Meaning, Nature, Origins, and Implications 